\title{
Strategy for Ensuring Food Security in India: Bridging the Link between Food Security and Agriculture Development
}

\author{
Akanksha Pandey ${ }^{1 *}$, V.K. Sharma ${ }^{2}$ and P.K. Pandey ${ }^{3}$ \\ ${ }^{1}$ Department of Agricultural Extension IGKV Raipur C.G., India \\ ${ }^{2}$ Department of Agricultural Economics SHUATS Allahabad U.P., India \\ ${ }^{3}$ IGKV, Raipur, C.G. 492012, India \\ *Corresponding author
}

\section{A B S T R A C T}

Food security is the most crucial as it hampers the development of the people as well as the nation. The global community often uses the term "food security" to describe not only the availability of food, but the ability to purchase food. Worldwide, 2.5 billion people derive

\section{Keywords}

Food security, Development, Extension, Agriculture, India

Article Info

Accepted: 26 April 2018 Available Online: 10 May 2018 their livelihoods from agricultural resources; 900 million poor people live in rural they directly depend on agriculture and related activities. Improving the productivity, profitability, and sustainability of smallholder farming using "agriculture for development" is the main pathway out of poverty, with innovation through science and technology being one of the key instruments (World Development Report, 2008). Research for development in agriculture and extension services has been a strong driving force for meeting food supply around the world as well as India. Increase in agricultural production through active involvement of small farmers and weaker sections of the society can empower the rural poor to earn their livelihood and improve their quality of life. Hence, agricultural development deserves priority for achieving the goal of food security in India. Positive outcomes can only be achieved when people access more and better food, as well as change their attitudes and practices towards improved nutritional food behavior. Stagnation in agricultural production has also been suppressing the employment opportunities in this sector. This has been affecting the income of the rural families and their capacity to purchase food. The objective of this study is to assess the link between food security and agricultural development in India.

\section{Introduction}

The world is currently facing the huge challenge of achieving food and nutrition security for a growing population with more diverse consumption patterns in the face of increasingly scarce natural resources and impacts of climate change. Ensuring food security ought to be an issue of great importance for a country like India where more than one-third of the population is estimated to be absolutely poor and one-half of all children malnourished. The commonly accepted definition of food security is when all people, at all times, have physical, social, and economic access to sufficient, safe, and nutritious food to meet their dietary needs and food preferences for an active and healthy 
life. Estimates of hunger based on some reviews; data shows that the proportion of households suffering from hunger declined from 17.3 per cent in 1983 to 2.5 per cent in 2004-05. This percentage is the highest 11.1 $\%$ in West Bengal followed by Orissa $5.9 \%$ and Assam $5 \%$ in 2004-05.

Almost 60 per cent of the Indian population continue to depend on agriculture and allied activities for their livelihood. The evidence from across the country shows the need for considerable investment in adaptation and mitigation actions toward a "climate-smart food system" that is more resilient to climate change influences on food security. Enhancing productivity and value of agricultural products is the important for enabling farmers to enter a virtuous circle of sustainable agricultural production and livelihood. Demand-driven, pluralistic advisory and extension systems with motivated, skilled professionals and effective use of modern informationcommunication technologies (ICT) will be required for making sustainable agriculture and nutritional food security a reality.

To both generate new knowledge and provide local agriculture solutions for farmers they need to have strong links and understanding of adaptive research within relevant agroecologies. Realizing this vision will require transformative institutional changes of current agricultural production systems in India.

\section{Challenges for agricultural production}

Abundant food insecurity,

Demand for food will increase because of vast population growth,

Unsustainable use of natural resources such as soil, biological diversity and water,

Most of the ecosystem services are degraded
Intensive agriculture is depends on high energy or resources but could be energy selfreliant and could mitigate GHG emission considerably

Agriculture is insufficiently prepared to cope with unpredictability and adaptation to climate change.

In rural areas most of the facilities like road, storage infastructures, ICTs tools are not available. Whereas $70 \%$ of the world's poor live in rural areas.

$90 \%$ of farms in the world are less than 2 ha covering $60 \%$ of the arable land worldwide.

Widespread subsistence production in isolated and marginal locations with low levels of technology.

Widespread food insecurity in spite of sufficient food being produced at global level food.

"Every man, woman and child has the inalienable right to be free from hunger and malnutrition in order to develop fully and maintain their physical and mental faculties"(Source: United Nations 1974) However, today, more than 800 million men, women and children are denied the most basic human right of all: the right to food. "Food and Nutrition Security" emphasizing several aspects, i.e., not only 'Availability', 'Accessibility', but also 'Use and Utilization' of food. Availability, Accessibility, Use and Utilization of food and the Stability of these three elements differ in their nature, causes and effects at the Macro, Meso and Micro level respectively. For example, food may be available in a country but not in certain disadvantaged districts or among discriminated population groups. The seasonality of food availability and utilization, for example, due to cyclic appearance of 
diseases, may be a rural but not an urban phenomenon.

The Figure 1. shows that to increasing productivity of agriculture in a sustainable manner from the focus on increasing productivity alone, there is need to holistic intigration of natural resources management with food and nutritional security. Effort to increase production and improved agricultural productivity are based on the development of existing subsistance farming system and its gradual diversification into commercial agriculture. Natural resources (soil, water, forestry, marine resources) are managed in a sustainable manner with the paricipation of rural communities. The development is balanced between social, environmental and economic development.

\section{Problems of food production}

Increasing population and their dependence on agriculture, small and fragmented land holdings, depletion of soil productivity, and inefficient use of water resources, out-dated agricultural production technologies, lack of agricultural credit and infrastructure for postharvest management and marketing of agricultural produce are responsible for low yield and income. Livestock is another source of income but severe genetic erosion over the years and neglect of nutrition and health care, have turned this asset into a liability. When the yields of crops and livestock are low, farmers earn lower income and naturally, the employment opportunities are also reduced. Unemployment leads to poverty, malnutrition, ill-health, neglect of women, high infant mortality and illiteracy. Improvement in agricultural production can address these problems drastically.

The increase in total production of different crops during the last 60 years is presented in Table 1. It generated employment for landholders as well as landless while ensuring food security for the India. In the 1990s, the growth in the agricultural sector started facing stagnancy especially in the pulses. There was a gradual decline in the growth of agricultural production, which dropped from $10-12 \%$ the 90's (Eighth Five Year Plan Period). The growth in production further reduced to $2.5 \%$ during the Ninth Plan Period and to $2.3 \%$ during the Tenth Plan Period. Stagnation in agricultural production has also been suppressing the employment opportunities in this sector. This has been affecting the income of the rural families and their capacity to purchase food. Thus, the per capita food consumption in rural India has been decreasing.

Reduction in the rate of growth in food production had several adverse effects on the farmers, particularly the poor. As can be seen in Table 2, the per capita availability of food grains declined after 1990. While the availability of rice and wheat marginally declined, there was a drastic reduction in the availability of coarse cereals and pulses.

This had a direct impact on the supply of protein and minerals, which accelerated the incidences of malnutrition particularly among pregnant women and children in India.

\section{Approaches to food security and agricultural development in India}

In the Indian context issue of food security should be viewed much beyond food availability. For eradicate the hunger in India different policies, such as effective implementation of anti-poverty programmes, decentralisation of procurements, control of inflation, improvement in primary healthcare and sanitation facilities, education facilities, employment generation etc. are very much needed for the betterment of food security in the country. 
Fig.1 Increasing sustainable agricultural productivity

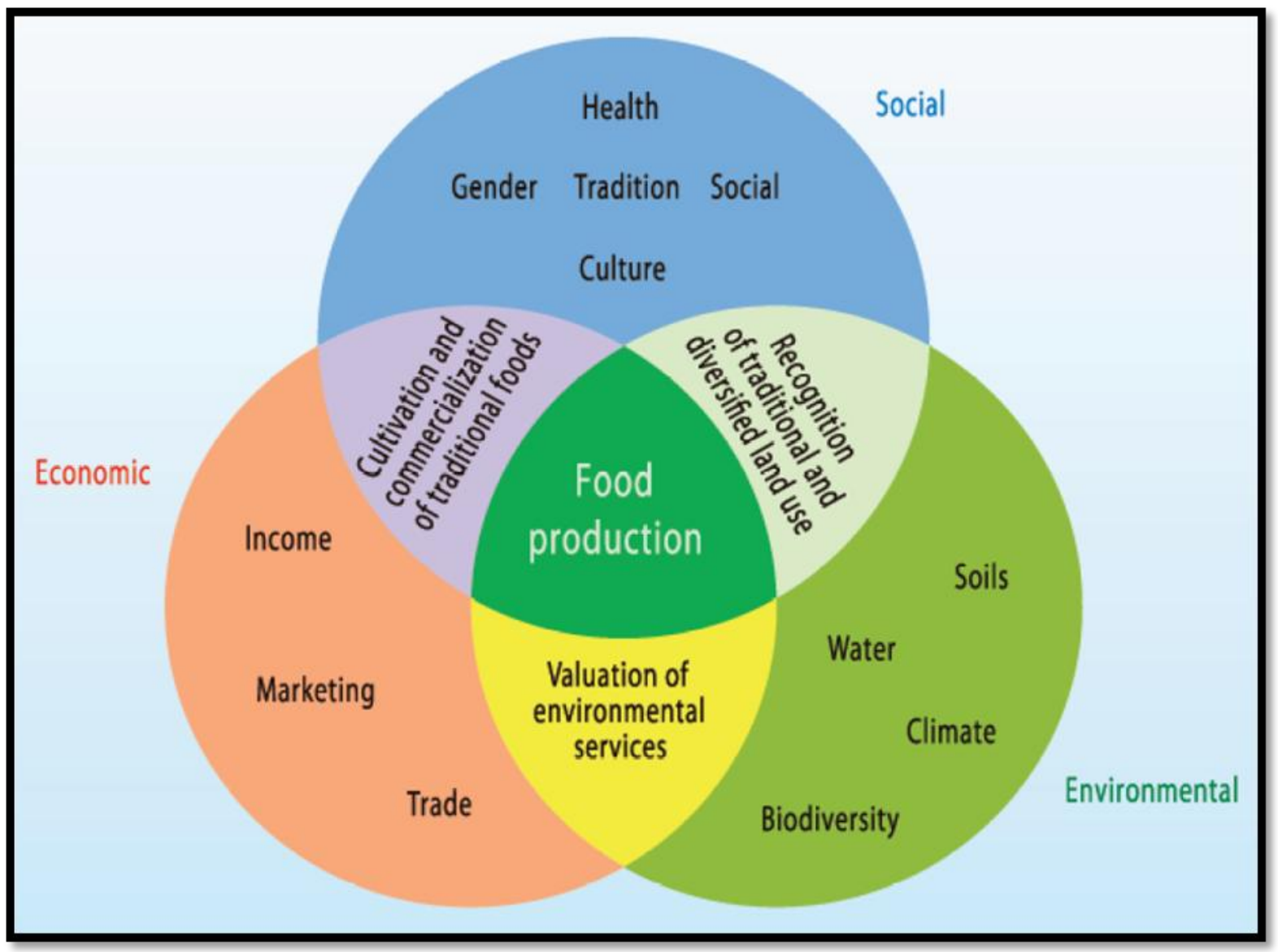

Table.1 Growth in different food grain production in India

\begin{tabular}{|c|c|c|c|c|c|}
\hline \multirow{2}{*}{ Year } & \multicolumn{5}{|c|}{ Food Crop Production (million tons) } \\
\hline & Rice & Wheat & $\begin{array}{c}\text { Coarse } \\
\text { Cereals }\end{array}$ & Pulses & $\begin{array}{c}\text { Total food } \\
\text { grains }\end{array}$ \\
\hline $\mathbf{1 9 5 0 - 5 1}$ & 20.58 & 6.46 & 15.38 & 8.41 & 50.82 \\
\hline $\mathbf{1 9 6 0 - 6 1}$ & 34.58 & 11 & 23.74 & 12.7 & 82.02 \\
\hline $\mathbf{1 9 7 0 - 7 1}$ & 42.22 & 23.83 & 30.55 & 11.82 & 108.43 \\
\hline $\mathbf{1 9 8 0 - 8 1}$ & 53.63 & 36.31 & 29.02 & 10.63 & 129.59 \\
\hline $\mathbf{1 9 9 0 - 9 1}$ & 74.29 & 55.14 & 32.7 & 14.26 & 176.39 \\
\hline $\mathbf{2 0 0 0 - 0 1}$ & 84.98 & 69.68 & 31.08 & 11.07 & 196.81 \\
\hline $\mathbf{2 0 1 0 - 1 1}$ & 95.32 & 85.93 & 42.20 & 18.09 & 241.56 \\
\hline
\end{tabular}

Source- Government of India, 2011. 
Table.2 Per capita availability of food grains in India

\begin{tabular}{|c|c|c|c|c|c|}
\hline Year & Rice & Wheat & Other Cereals & Pulses & Food grains \\
\hline 1951 & 58.0 & 24.0 & 40.0 & 22.1 & 144.1 \\
\hline 1961 & 73.4 & 28.9 & 43.6 & 25.2 & 171.1 \\
\hline 1971 & 70.3 & 37.8 & 44.3 & 18.7 & 171.1 \\
\hline 1981 & 72.2 & 47.3 & 32.8 & 13.7 & 166.0 \\
\hline 1991 & 80.9 & 60.0 & 29.2 & 15.2 & 186.2 \\
\hline 2001 & 69.5 & 49.6 & 20.5 & 10.9 & 151.9 \\
\hline 2010 & 64.0 & 53.0 & 19.7 & 15.3 & 159.2 \\
\hline
\end{tabular}

Source- Government of India, 2011.

For achieving food security in India as well as achieving maximum agricultural production, several policy instruments were used that influenced agricultural production potential.

Establishment, strengthening and expansion of agricultural education, extension and training system for agricultural extension workers and farmers for transfer of new technologies at the farm level.

Creation, strengthening and expansion of the national agricultural research system (NARS) for developing new production technologies for food grains and other agricultural products.

An arrangement for the production and distribution of high-yielding farm inputs like improved seeds, fertilizers, agrochemicals and improved implements/farm machines to the farmers.

Planning and execution of major, medium, and micro irrigation schemes for increasing the area under irrigation.

Creation and expansion of physical and institutional infrastructure like; primary market yards, roads, storage facilities, farmers' cooperatives and public sector organizations for improvement of the agricultural production and marketing system.
Building-up and maintenance of buffer stocks of food grain, pulses and distribution of these through public distribution system.

Provision of food and input subsidies, crop insurance, other agricultural finance for all categories of farmers in India.

Today, the world has more than enough food to feed everyone, yet millions are food insecure. Achieving food security requires adequate food availability, access, and use. Agriculture plays a key role in providing food; food availability globally, an important source of income to purchase food, and foods with high nutritional status. In the future, agriculture will continue to play a central role in tackling the problem of food insecurity. It can maintain and increase global food production, ensuring food availability. It can be the primary means to generate income for the poor, securing their access to food.

\section{References}

Acharya S.S. (2009). Food Security and Indian Agriculture: Policies, Production Performance and Marketing Environment. Agricultural Economics Research Review Vol. 22 pp 1-19

Dev S.M. and Sharma A. N. (2010) Oxfam India working papers series OIWPS VII 
FAO (2010). The State of Food Insecurity in the World. Food and Agriculture Organization of the United Nations. Rome, Italy.

Government of India. (2011). Faster, Sustainable and More Inclusive Growth - An Approach to he XII Five Year Plan, Planning Commission, New Delhi.
Hegde N.G. Strategy for ensuring food security in India baif development research foundation, Pune

Mozumdar (2012). Agricultural productivity and food security in the developing world. Bangladesh J. Agric. Econs. XXXV, 1\&2(2012) 53-69

World Bank (2007). World Development Report 2008: Agriculture for Development. Washington, DC, World Bank.

\section{How to cite this article:}

Akanksha Pandey, V.K. Sharma and Pandey, P.K. 2018. Strategy for Ensuring Food Security in India: Bridging the Link between Food Security and Agriculture Development. Int.J.Curr.Microbiol.App.Sci. 7(05): 3500-3505. doi: https://doi.org/10.20546/ijcmas.2018.705.404 